\title{
FAKTOR DETERMINAN AUDIT REPORT LAG PADA PERUSAHAAN MANUFAKTUR YANG TERDAFTAR DI BURSA EFEK INDONESIA TAHUN 2017-2019
}

\author{
Novi Akhsani ${ }^{1)}$, Zulfa Rosharlianti $^{2)^{*}}$, Anisa $^{3)}$ \\ ${ }^{1}$ Fakultas Ekonomi dan Bisnis, Universitas Pamulang \\ email: dosen00887@unpam.ac.id \\ ${ }^{2}$ Fakultas Ekonomi dan Bisnis, Universitas Pamulang \\ email: dosen00876@unpam.ac.id \\ ${ }^{3}$ Fakultas Ekonomi dan Bisnis, Universitas Pamulang \\ email: dosen02385@unpam.ac.id
}

\begin{abstract}
This study aims to determine the description and determinants of audit report lag factors in manufacturing companies listed on the Indonesia Stock Exchange in 2017-2019. The research independent variable is financial distress, investment opportunity and KAP reputation, while the dependent variable is audit report lag. Samples were taken through purposive sampling, in order to obtain a number of 31 companies. Data analysis techniques used multiple linear regression panel data Random Effect Model. The results of this study are that together financial distress, investment opportunity and KAP reputation have a significant effect on audit report lag. Partially, financial distress has no effect on the audit report lag, investment opportunity has no effect on the audit report lag, and the reputation of KAP has no effect on the audit report lag.
\end{abstract}

Keywords: financial distress, investment opportunity, reputation of $K A P$, audit report lag

\begin{abstract}
ABSTRAK
Penelitian ini bertujuan mengetahui gambaran dan determinan faktor audit report lag pada perusahaan manufakturing yang terdaftar di Bursa Efek Indonesia pada tahun 2017-2019. Variable independen penelitian yaitu financial distress, investment opportunity dan reputasi KAP, sedangkan variable dependen yaitu audit report lag. Sampel diambil melalui purposive sampling, sehingga didapatkan sejumlah 31 perusahaan. Teknik analisis data memakai regresi linear berganda data panel Random Effect Model. Hasil dari penelitian ini yaitu secara bersama-sama financial distress, investment opportunity dan reputasi KAP berpengaruh secara signifikan terhadap audit report lag. Secara parsial financial distress tidak berpengaruh terhadap audit report lag, investment opportunity tidak berpengaruh terhadap audit report lag, dan reputasi KAP tidak berpengaruh terhadap audit report lag.
\end{abstract}

Kata Kunci: financial distress, investment opportunity, reputasi KAP, audit report lag 


\section{PENDAHULAN}

Dilansir dari CNN Indonesia, 30 Juni 2016 PT Bursa Efek Indonesia (BEI) memberikan sanksi serta memberhentikan sementara perdagangan saham 18 emiten sebab tidak menyerahkan laporan keuangan yang ditinjau untuk masa 31 Desember 2015. Bursa melaksanakan penangguhan apabila penyampaian laporan keuangan melampaui batas waktu yang ditentukan yaitu mulai kalender ke-91. Perihal itu pula berlaku kepada emiten yang sudah mengantarkan laporan keuangan, namun tidak melaksanakan kewajibannya dalam membayar sanksi.

Tahun 2017, BEI kembali melaksanakan suspensi serta penarikan sanksi kepada 17 industri yang tercatat di BEI disebabkan industri tersebut belum mengantarkan laporan keuangan audit per 31 Desember 2016 serta belum mengantarkan sanksi atas kelalaian penyampaian laporan keuangan (www. liputan6.com, 3 Juli 2017). Sampai dengan tahun 2018, masih ada industri yang diganjar hukuman berbentuk masa penghentian yang diperpanjang sedangkan perdagangan saham serta sanksi pada 8 industri disebabkan belum menuntaskan beberapa kewajiban yang berkaitan dengan pelaporan keuangan industry (www. investasi. kontan. co. id, 2 Juli 2018) dalam (Mufidah \& Laily, 2019)

Mengingat Pernyataan Badan Pengurus BEJ tentang Peraturan Nomor IH tentang hukuman yang diberikan kepada penjamin, mengacu pada pengaturan II.6.2 (Teguran Tersusun II) pedoman menjelaskan bahwa denda adalah Rp. 50.000.000.00, apabila mulai hari ke-31 sampai dengan hari ke-60 dari due date penyampaian laporan keuangan, organisasi sebenarnya belum memenuhi komitmen untuk menyampaikan ikhtisar anggaran dan pedoman II.6.3 (Teguran Tersusun III) menyatakan bahwa ada denda tambahan sebesar Rp. 150.000.000.00 apabila organisasi ternyata belum memenuhi komitmen menyampaikan laporan keuangan ataupun belum membayar sanksi yang dimaksud dalam pedoman II.6.2. Kepala Penilai BEI juga akan menghentikan sementara saham-saham organisasi jika mulai hari ke-91 sejak due date penyampaian ringkasan fiskal, mereka sebenarnya tidak memenuhi komitmen untuk menyampaikan laporan keuangan sehubungan dengan Akomodasi Laporan Tahunan Pendukung atau Organisasi Publik yang menyatakan bahwa untuk setiap organisasi terbuka yang tercatat di BEI wajib mengirimkan annual report kepada BAPEPAM dan Yayasan Moneter paling lambat 120 hari setelah tahun anggaran berakhir. Kelonggaran panjang laporan review mempengaruhi nilai ikhtisar fiskal yang diperiksa. Karena penundaan penyampaian laporan keuangan yang diperiksa menunjukkan pertanda buruk dari organisasi bagi individu yang berinvestasi. Dan Semakin banyak laporan keuangan tertunda, membuat nilai- nilai yang relevan dalam laporan tersebut diragukan oleh para pemangku kepentingan.

Audit report lag merupakan rentang waktu antara akhir tahun atau tahun moneter dan tanggal yang dinyatakan dalam laporan tinjauan. Kerangka waktu ini menunjukkan rentang waktu penguji telah menyelesaikan pekerjaan ulasannya (Parahyta \& Herawaty, 2020). Semakin lama penundaan laporan tinjauan, semakin banyak waktu yang diperlukan untuk menerbitkan ringkasan fiskal yang diperiksa oleh peninjau, terlepas dari apa yang mungkin diharapkan, semakin terbatas rentang waktu antara akhir tahun dan tanggal dalam laporan tinjauan, semakin cepat sehingga terhindar dari denda yang diberikan oleh Bapepam.

Berdasarkan Keputusan Ketua BAPEPAM-LK Nomor: KEP431/BL/2012 : Apabila suatu perusahaan dalam keadaan 
kondisi keuangan yang buruk dan terjadi secara terus menerus akan menyebabkan kebangkutan. Keadaan inilah yang disebut dengan financial distress. Menurut (Parahyta \& Herawaty, 2020) bahwa apabila perusahaan memiliki kondisi financial distress dapat mempengaruhi risiko audit yang makin tinggi yaitu risiko pengendalian sehingga akan berpengaruh terhadap audit report lag.

Ringkasan fiskal adalah data penting bagi para pendukung keuangan, terutama tentang manfaat, ringkasan laba dalam anggaran adalah petunjuk pelaksanaan organisasi dan digunakan sebagai alat pemikiran dalam menentukan pilihan usaha sehingga kelonggaran laporan tinjauan yang mudah dipotong akan menyebabkan tanggapan negatif dari pasar. Ketika dalam laporan keuangan perusahaan tidak terjadi laba (loss), pengelola mengupayakan untuk menyembunyikan bad news ini dengan tujuan agar masyarakat umum tidak mengetahuinya. Administrator dan evaluator akan berkolaborasi untuk menutupi hal tersebut dengan menghalangi pelaksanaan review, atau meminta inspektur untuk menjadwal ulang siklus review.

Hal ini dilakukan mengingat fakta bahwa untuk organisasi tertentu yang mengalami kerugian, kerugian ini akan menyebabkan pendukung keuangan bertanya-tanya apakah akan memasukkan sumber daya ke dalam saham di organisasi mereka atau tidak. Jadi organisasi akan mengambil pendekatan yang berbeda untuk menutupi kejadian ini, dengan memperlambat laporan fiskalnya. Oleh karena itu, pemeriksa yang menemukan rincian kerugian dalam laporan keuangan akan lebih aware dalam interaksi pemeriksaan, dan akan memimpin pemeriksaan tambahan untuk mengungkapkan bukti sasaran yang mendukung pengesahan yang terkait dengan pengelolaan bisnis organisasi yang diperiksa. Review tambahan yang diselesaikan oleh evaluator jelas membutuhkan waktu ekstra sehingga berpengaruh pada perluasan laporan slack report (Sawitri \& Budiartha, 2018).

Penelitian-penelitian sebelumnya mengenai financial distress dan investment opportunity terhadap audit report lag sudah banyak dilakukan antara lain penelitian yang dilakukan oleh (Himawan, 2020) menyatakan bahwa Masalah keuangan secara signifikan mempengaruhi kelonggaran laporan keuangan karena keadaan organisasi dengan tingkat risiko keuangan yang tidak dapat disangkal mendorong organisasi untuk memperbaiki sifat laporan keuangan yang buruk, sehingga upaya ini dapat mempengaruhi lamanya penundaan laporan keuangan. Selain itu, pemeriksa diminta untuk merencanakan siklus peninjauan lebih lama dari yang seharusnya, sehingga hal ini berdampak pada keterlambatan penyampaian laporan anggaran. Dan dalam penelitian (Putri, 2019) menguji hubungan antara audit report report lag dengan investment opportunities. Hasil penelitian mengungkapkan bahwa penundaan laporan ulasan lebih lama untuk organisasi dengan peluang spekulasi yang lebih tinggi, penelitian ini juga menunjukkan bahwa organisasi kecil, organisasi yang jatuh dan organisasi yang memiliki kelemahan signifikan dalam kontrol internal mereka, biasanya memiliki penundaan yang lebih lama dalam meninjau dan mengumumkan masalah.

Objek penelitian ini adalah perusahaan manufaktur karena berdasarkan berita dalam artikel kontan.co.id perusahaan manufaktur merupakan perusahaan yang paling banyak terjerat Penundaan Kewajiban Pembayaran Utang (PKPU) sepanjang tahun 2018 ada 69 permohonan PKPU, dan 17 permohonan pailit. Di Indonesia jumlah perusahaan manufaktur cukup banyak yang terdaftar di BEI dibandingkan dengan perusahaan di sektor lainnya. Maka dengan kondisi keuangan yang buruk serta peluang investasi yang 
tinggi merupakan faktor yang mendorong perusahaan dibidang manufaktur terlambat menyampaikan laporan keuangannya.

Berdasarkan uraian diatas, motivasi dalam penelitian ini adalah kesadaran akan pentingnya penyampaian laporan keuangan secara tepat waktu maka, auditor harus mengetahui dan mengendalikan faktor-faktor yang mempengaruhi hal tersebut. Oleh karena itu penulis tertarik untuk mengambil judul "Faktor Determinan audit report lag pada Perusahaan Manufaktur yang terdaftar di Bursa Efek Indonesia Tahun 2017 2019".

\section{KAJIAN LITERATUR}

Audit report lag adalah rentang waktu antara tahun fiskal atau tahun tutup buku dengan tanggal yang dicantumkan pada laporan pemeriksaan. Kerangka waktu ini memperlihatkan rentang waktu auditor dalam menyelesaikan pekerjaan peninjauannya (Parahyta \& Herawaty, 2020). Semakin berlarut-larut audit report lag, menyebabkan semakin banyak waktu yang diperlukan untuk menerbitkan ikhtisar laporan keuangan yang diperiksa auditor, sebaliknya semakin terbatas interval waktu antara tahun tutup buku dan tanggal dalam laporan pemeriksaan, semakin cepat dalam mempublikasi laporan keuangan yang diperiksa oleh auditor diterbitkan sehingga denda yang diberikan oleh Bapepam pun dapat dihindari.

Pengukuran yang digunakan adalah estimasi jangka waktu penyelesaian tinjauan dari tanggal akhir tahun anggaran sampai dengan tanggal distribusi laporan anggaran yang telah dievaluasi oleh reviewer. Dengan rumus sebagai berikut:

Audit Report Lag $=$ Tanggal Laporan Audit - Tanggal Laporan Keuangan

Financial Distress adalah suatu organisasi yang memiliki kondisi keuangan yang memburuk sehingga jika keadaan ini berulang terus menerus akan menimbulkan kebangkutan. Dalam kondisi ini perusahaan tidak mampu membayar kewajiban-kewajibannya sehingga kondisi ini menyebabkan kewajiban lebih besar dibandingkan dengan kekayaan (Alfatika, 2017) selain itu menurut (Parahyta \& Herawaty, 2020) Financial distress terjadi karena pendapatan bernilai negatif, aset berubah dan kewajiban dalam laporan posisi keuangan serta dipengaruhi oleh suku bunga dan tarif pajak yang ditetapkan oleh pemerintah.

Saat perusahaan dalam kondisi ini menyebabkan auditor dalam mengaudit memerlukan waktu yang lebih panjang sehingga hal ini berdampak pada naiknya risiko audit yaitu risiko deteksi dan risiko pengendalian (Parahyta \& Herawaty, 2020).

Pengukuran financial distress pada penelitian ini menggunakan Debt to Equity Ratio. Rasio ini dianggap pengukuran yang paling tepat untuk digunakan. Rasio DER digunakan untuk menentukan seberapa baik organisasi mengelola utang yang digunakannya sebagai modal. Berikut adalah rumus Rasio DER:

$$
D E R=\frac{\text { Total Liability }}{\text { Total Equity }} \times 100 \%
$$

Investment Opportunity merupakan tersedianya aksesibilitas opsi usaha di kemudian hari untuk perusahaan (Putri, 2019). IOS beranggapan bahwa nilai dari suatu organisasi sebagai penggabungan antara asset in place dengan investment option pada masa yang akan datang. IOS adalah nilai organisasi yang jumlahnya bergantung pada konsumsi yang ditetapkan para eksekutif di kemudian hari, yang sampai sekarang merupakan keputusan spekulasi yang diperlukan untuk menghasilkan pengembalian yang lebih tinggi. 
Investment Opportunity pada penelitian ini menggunakan proksi perhitungan Market Value to Book Value of Equity Ratio (MVE/BE). MVE/BE adalah salah satu pengukuran yang memiliki hubungan yang tinggi dengan Investment Opputunitie Set. MVE/BVE dirumuskan sebagai berikut:

$\frac{M V E}{B V E}=\frac{\text { lembar saham beredar } x \text { Harga saham }}{\text { Total Ekuitas }}$

Reputasi Kantor Akuntan Publik adalah pandangan atas prestasi, nama besar dan kepercayaan masyarakat yang diperoleh KAP. Waktu pemeriksaan yang lebih singkat menjadi jalan bagi KAP agar dapat menjaga posisinya sehingga tidak kehilangan pelanggan (Sunaningsih \& Rohman, 2013) dalam (Isnania et al., 2018).

Untuk membangun kepercayaan dari laporan audit, organisasi menggunakan KAP bereputasi baik. KAP bereputasi baik yakni anak perusahaan dengan KAP yang tersebar luas seperti Big Four Worldwide Accounting Firm (Big 4). (Isnania et al., 2018) mengatakan bahwa KAP yang merupakan anak perusahaan Big Four lebih dulu menyelesaikan pemeriksaannya dibandingkan KAP non Big Four. Hal ini karena KAP Big Four mempunyai aksesibilitas inovasi, teknologi serta SDM yang lebih ahli untuk membuat proses audit menjadi lebih efektif dan efisien.

Reputasi KAP dalam penulisan ini menggunakan pengukuran dummy. Perusahaan yang diaudit oleh KAP Big Four diberi kode (1) sedangkan perusahaan yang diperiksa oleh KAP Non Big Four diberi kode (0). Dengan rumus sebagai berikut:

$$
\begin{gathered}
\text { KAP BIG FOUR }=1 \\
\text { KAP NON BIG FOUR }=0
\end{gathered}
$$

Kerangka pemikiran dalam penelitian ini yang menghubungkan antara financial distress, investment opportunity dan reputasi KAP dengan audit report lag adalah sebagai berikut:

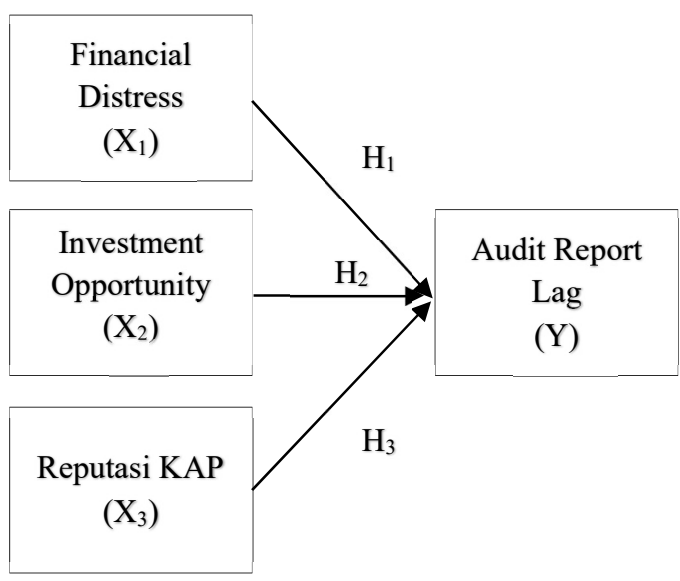

Gambar 1. Kerangka Pemikiran

Hipotesis dalam penelitian ini didasarkan pada rangka pemikiran diatas adalah:

$\mathrm{H}_{1}$ : Diduga Financial Distress terhadap Audit Report Lag

$\mathrm{H}_{2}$ : Diduga Investment Opportunity terhadap Audit Report Lag

$\mathrm{H}_{3}$ : Diduga Reputasi KAP terhadap Audit Report Lag

\section{METODE PENELITIAN}

Riset ini menggunakan sumber informasi yang diperoleh pada web BEI dengan metode kuantitatif. Populasinya adalah perusahaan manufacturing yang terdaftar di BEI. Jumlah populasi penelitian sebanyak 31 perusahaan. Teknik pengambilan sampel yaitu purposive sampling. (Wiratna, 2014) mendefinisikan purposive sampling adalah teknik penentuan sampel dengan kriteria tertentu.

Strategi pengumpulan data informasi yang penulis gunakan dalam penelitian ini adalah studi dokumentasi dan studi pustaka. Studi pustaka diselesaikan dengan mengolah informasi, jurnal, artikel ataupun media tertulis lainnya yang berhubungan dengan penelitian ini. Studi dokumentasi merupakan strategi untuk mengumpulkan data sekunder yang digunakan untuk menyelesaikan penelitian ini seperti ringkasan annual report perusahaan. 


\section{HASIL DAN PEMBAHASAN}

\section{Uji Asumsi Klasik}

Uji Normalitas

Uji normalitas menunjukkan variabel independen terdistribusi normal atau tidak.
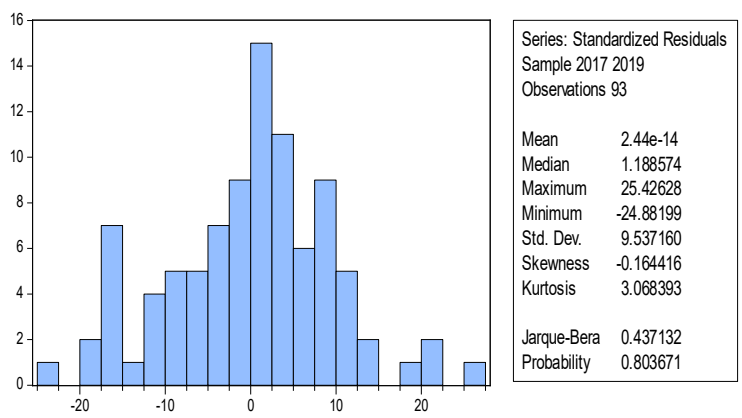

Gambar 2. Hasil Uji.Normalitas

Berdasarkan gambar 2. uji normalitas menggunakan JarqueBerra dapat dilihat bahwa nilai probabilitas sebesar 0.803671 $>0.05$ maka diambil kesimpulan data terdistribusi normal.

\section{Uji Multikolinearitas}

Uji multikolinearitas menunjukkan adanya korelasi pada regresi antar variabel independen. Berikut hasil ujinya:

\begin{tabular}{cccc}
\multicolumn{4}{c}{ Tabel 1. Hasil Uji Multikolinearitas } \\
FD & IOS & KAP \\
FD & 1.000000 & -0.090059 & -0.112456 \\
IOS & -0.090059 & 1.000000 & 0.402144 \\
KAP & -0.112456 & 0.402144 & 1.000000
\end{tabular}

Berdasarkan tabel 1. penelitian ini menggunakan matriks korelasi variabel independen. Dapat dilihat bahwa matriks korelasi diatas tidak lebih dari 0.90 . Ditarik kesimpulan bahwa data ini tidak terkena multikolinearitas.

\section{Uji Heteroskedastisitas}

Uji.heteroskedastisitas menunjukkan ada atau tidaknya perbedaan variance residual dari variabel independen.

Tabel 2. Hasil Uji.Heteroskedastisitas

\begin{tabular}{crrrr}
$\begin{array}{c}\text { Variab } \\
\text { le }\end{array}$ & Coefficient & Std. Error & t-Statistic & Prob. \\
\hline \hline KAP & 3.255827 & 1.710743 & 1.903165 & 0.0603 \\
IOS & -0.953971 & 0.961310 & -0.992366 & 0.3237 \\
FD & 0.461441 & 1.630763 & 0.282960 & 0.7779 \\
C & 7.046029 & 1.928919 & 3.652838 & 0.0004
\end{tabular}

Berdasarkan tabel 2. penelitian ini memakai uji park nilai probabilitas variabel independen tidak ada yang dibawah 0.05. Sehingga data tersebut tidak terkena heteroskedastisitas.

\section{Uji Autokorelasi}

Uji autokorelasi menunjukkan korelasi antar residual satu dengan pengamatan lain.

\section{Tabel 3. Hasil Uji Autokorelasi}

$$
\text { Weighted Statistics }
$$

$\begin{array}{lrll}\text { R-squared } & 0.035297 & \text { Mean dependent var } & 46.84153 \\ \text { Adjusted R-squared } & 0.002779 & \text { S.D. dependent var } & 7.687947 \\ \text { S.E. of regression } & 7.677257 & \text { Sum squared resid } & 5245.684 \\ \text { F- statistic } & 1.085462 & \text { Durbin-Watson stat } & 1.938760 \\ \text { Prob (F-statistic) } & 0.000000 & & \end{array}$

Sesuai dengan tabel 3. nilai DW sebesar 1.938760 lebih dari nilai dL dalam tabel DW yaitu 1.59661. Sehingga diambil kesimpulan penelitian ini tidak terkena autokorelasi. Sehingga perhitungannya adalah sebagai berikut:

$\mathrm{dU} 1.72954<1.93876<4-\mathrm{dU}=2.27046$

$\rightarrow$ Tidak terjadi autokorelasi

\section{Uji Hipotesis}

\section{Analisis Regresi Linier Berganda}

Uji hipotesis digunakan untuk menguji hipotesis dan mengetahui determinan faktor variabel bebas terhadap variable terikat secara bersama-sama maupun parsial dalam penelitian ini.

Tabel 4. Analisis Regresi Linear Berganda

\begin{tabular}{crrrr}
$\begin{array}{c}\text { Variab } \\
\text { le }\end{array}$ & Coefficient & Std. Error & t-Statistic & Prob. \\
\hline \hline KAP & 3.255827 & 1.710743 & 1.903165 & 0.0603 \\
IOS & -0.953971 & 0.961310 & -0.992366 & 0.3237 \\
FD & 0.461441 & 1.630763 & 0.282960 & 0.7779 \\
C & 7.046029 & 1.928919 & 3.652838 & 0.0004
\end{tabular}

Dari Tabel 4. menghasilkan persamaan regresi linier berganda data panel:

$$
\begin{aligned}
\mathrm{Y}=7.046029 & +0.461441 \mathrm{X}_{1}-0.953971 \mathrm{X}_{2} \\
& +3.255827 \mathrm{X}_{3}
\end{aligned}
$$

Berdasarkan persamaan regresi linear berganda data panel diatas dapat diinterpretasikan sebagai berikut : 
1. Financial Distress, Investment Opportunity dan Reputasi KAP bernilai konstanta yang bernilai positif yaitu 7.046029 artinya Audit Report Lag akan naik sebesar 7.046029.

2. Financial Distress bernilai koefisien positif yaitu 0.461441 mengartikan variable financial distress mengalami peningkatan $1 \%$ dan variable independen konstan artinya audit report lag akan naik sebesar 0.461441 .

3. Investment Opportunity bernilai koefisien negatif yaitu 0.953971 mengartikan variable investment opportunity mengalami peningkatan $1 \%$ dan variable independen konstan artinya audit report lag akan turun sebesar 0.953971.

4. Reputasi KAP koefisien positif yaitu 3.255827 mengartikan variable reputasi KAP mengalami peningkatan $1 \%$ dan variable independen konstan artinya audit report lag akan naik sebesar 3.255827 .

\section{Uji t}

Uji statistik $\mathrm{t}$ menunjukkan seberapa jauh variable independen mempengaruhi secara parsial terhadap variable dependen.

\section{Tabel 5. Hasil Uji t}

\begin{tabular}{cc} 
Variable & Prob. \\
\hline \hline KAP & 0.0603 \\
IOS & 0.3237 \\
FD & 0.7779 \\
C & 0.0004
\end{tabular}

Sesuai dengan tabel 5. hasil dari uji statistik t, yaitu :

1. Financial Distress bernilai koefisien sebesar 0.461441 , bernilai positif. Nilai probabilitas sebesar $0.7779>0.05$ artinya bahwa Financial Distress memiliki arah positif dan tidak signifikan terhadap Audit Report Lag.

2. Investment Opportunity bernilai koefisien sebesar 0.953971 bernilai negatif. Nilai probabilitas sebesar $0.3237>0.05$ artinya bahwa Investment Opportunity memiliki arah negative.dan tidak signifikan.terhadap Audit Report Lag.

3. Reputasi KAP bernilai koefisien sebesar 3.255827, bernilai positif. Nilai probabilitas sebesar $0.0603>0.05$ artinya bahwa Reputasi KAP memiliki arah positif dan tidak signifikan terhadap Audit Report Lag.

\section{Uji F}

Uji Statistik.F menunjukkan secara keseluruhan variable bebas terdapat pengaruh secara bersama-sama terhadap variable terikat atau tidak.

\section{Tabel 6. Hasil Uji F}

Weighted Statistics

$\begin{array}{lrll}\text { R- squared } & 0.035297 & \text { Mean dependent var } & 46.84153 \\ \text { Adjusted R-squared } & 0.002779 & \text { S.D. dependent var } & 7.687947 \\ \text { S.E. of regression } & 7.677257 & \text { Sum squared resid } & 5245.684 \\ \text { F- statistic } & 1.085462 & \text { Durbin-Watson stat } & 1.938760 \\ \text { Prob (F-statistic) } & 0.000000 & & \end{array}$

Berdasarkan tabel 6. diketahui bahwa nilai uji $F$ prob (Fstatistic) sebesar $0.000000<0.05$ maka tolak H0. Bisa diambil kesimpulan semua variable independen Financial Distress, Investment Opportunity, dan Reputasi KAP secara simultan ada pengaruh signifikan pada Audit Report Lag.

\section{Pengaruh Financial Distress terhadap Audit Report Lag}

Berdasarkan hasil regresi mengungkapkan bahwa financial distress mempunyai nilai signifikan sebesar 0.7779 , dimana nilai tersebut $0.7779 \geq \alpha=$ 0,05 yang memiliki arti financial distress tidak berpengaruh terhadap audit report lag. Meskipun tingkat DER nya tinggi, organisasi tidak bisa dianggap dalam kondisi financial distress atau menderita secara finansial. Tingkat kewajiban yang signifikan ini tidak mempengaruhi lamanya auditor dalam melakukan pemeriksaan. Jika manajemen risiko telah dikelola dengan baik oleh perusahaan, maka hal ini tidak akan meningkatkan risiko audit pada organisasi. 
Hasil penelitian ini sejalan dengan penelitian (Oftika Sari, Einde Evana, 2019) namun berbeda dengan penelitian (Himawan, 2020) dan (Alfatika, 2017) bahwa financial distress berpengaruh signifikan terhadap audit report lag.

\section{Pengaruh Investment Opportunity Set terhadap Audit Report Lag}

Berdasarkan hasil regresi menunjukkan bahwa investment opportunity set memiliki nilai signifikan sebesar 0.3237 , dimana nilai tersebut $0.3237 \geq \alpha=0,05$ yang berarti investment opportunity set tidak berpengaruh terhadap audit report lag. Perusaahan yang memiliki high investment opportunities akan memiliki kemampuan untuk menghasilkan keuntungan dari prospek pertumbuhan, hal ini membuktikan bahwa organiasai mempunyai performa yang baik untuk saat ini dan memiliki rencana matang dalam hal investasi perusahaan di masa depan. Akan tetapi investor awam jarang melihat prospek pertumbuhan akan tetapi pertumbuhan perusahaan untuk saat ini. Oleh karena itu investment opportunity set tidak berpengaruh terhadap audit report lag.

Hasil penelitian ini sejalan dengan penelitian (Putra Dewangga \& Majidah, 2016) yang menyatakan bahwa investment opportunity tidak berpengaruh terhadap audit report lag.

\section{Pengaruh Reputasi KAP terhadap Audit Report Lag}

Berdasarkan hasil regresi menunjukkan bahwa reputasi KAP memiliki nilai signifikan sebesar 0.0603 , dimana nilai tersebut $0.0603 \geq \alpha=0,05$ yang berarti reputasi KAP tidak berpengaruh terhadap audit report lag. KAP yang termasuk Big Four maupun non Big Four akan samasama berusaha menunjukkan tingginya profesionalisme mereka. Reputasi auditor bukan hanya dilihat dari nama besar KAP saja, tetapi juga pada kualitas audit yang disampaikan oleh KAP. Untuk KAP yang berkaitan dengan Big Four, kualitas hasil pemeriksaan perlu dipertahankan agar dapat menjaga citra mereka di mata masyarakat umum sehingga tetap dipercaya oleh klien untuk memberikan jasa pemeriksaan atau auditnya. Begitu juga dengan KAP non Big Four, sehingga KAP non Big Four bagaimanapun akan tetap dapat bersaing dengan anak perusahaan KAP Big Four.

Hasil penelitian ini tidak sesuai dengan hasil penelitian (Sawitri \& Budiartha, 2018) dan (Isnania et al., 2018). Namun hasil penelitian ini sejalan dengan penelitian yang dilakukan (Alfatika, 2017) dengan hasil bahwa reputasi KAP tidak berpengaruh terhadap audit report lag.

\section{KESIMPULAN DAN SARAN Kesimpulan}

Berdasarkan hasil analisis data dan pembahasan yang telah dikemukakan, maka simpulan yang dapat diambil dari penelitian ini adalah sebagai berikut:

1. Financial distress secara parsial tidak berpengaruh signifikan terhadap audit report lag.

2. Investment Opportunity Set secara parsial tidak berpengaruh signifikan terhadap audit report lag.

3. Reputasi KAP secara parsial tidak berpengaruh signifikan terhadap audit report lag.

\section{Saran}

1. Bagi Perusahaan yang akan mempublikasikanlaporan keuangannya harap memperhatikan waktu yang dibutuhkan untuk mengaudit laporan keuangan agar tidak terjadi keterlambatan penyampaian laporan keuangan audit ke Otoritas Jasa Keuangan (OJK) dan Bursa Efek Indonesia (BEI).

2. Bagi peneliti berikutnya yang masih berkaitan dengan audit report lag diharapkan bisa meneliti faktor lain.selain financial distress, investment opportunity set dan reputasi 
KAP ataupun dapat menggunakan proksi lain.

3. Peneliti selanjutnya didorong untuk mengembangkan uji eksplorasi. dengan objek pemeriksaan yang lebih luas dan untuk waktu yang lebih lama sehingga dapat lebih menggambarkan kondisi audit report lag dalam sebuah organisasi.

\section{DAFTAR PUSTAKA}

Alfatika, F. (2017). Pengaruh Auditor Switching, Reputasi KAP dan Financial Distress Terhadap Audit Report Lag (Studi Empiris pada Perusahaan Properti dan Real Estate yang Terdaftar di Bursa Efek Indonesia Tahun 2011-2015). Jurnal Akuntansi Unpam.

Bangun, P., Subagyo, \& Tarigan, M. U. (2012). Faktor-Faktor Yang Mempengaruhi Audit Report Lag Pada Perusahaan Yang Listed Di Bursa Efek IndonesIA. Pekan Ilmiah Dosen FEB-USKW.

Basuki, A. T., \& Prawoto, N. (2015). Analisis Regresi dalam Penelitian Ekonomi \& Bisnis. In PT Rajagrafindo Persada, Depok.

Connelly, B. L., Certo, S. T., Ireland, R. D., \& Reutzel, C. R. (2011). Signaling theory: A review and assessment. In Journal of Management. https://doi.org/10.1177/01492063103 88419

Godbey, J. M., \& Mahar, J. W. (2004). Implied Volatilities And Auditor Reputation: The Andersen Case. In Research in Finance. https://doi.org/10.1016/S01963821(04)21004-8

Himawan, F. A. dan V. (2020). Analisis Pengaruh Financial Distress, Leverage, Profitabilitas, Dan Likuiditas Terhadap Audit Report Lag Pada Perusahaan Manufaktur Sektor Industri Barang Konsumsi Yang Terdaftar Di Bursa Efek Indonesia Tahun 2014-2018. Jurnal
Manajemen Bisnis.

Iskandar, M. J., \& Trisnawati, E. (2010). Faktor-Faktor Yang Mempengaruhi Audit Report Lag Pada Perusahaan Yang. Jurnal Bisnis Dan Akuntansi.

Isnania, S. A., Sukarmanto, E., \& Maemunah, M. (2018). Pengaruh komite audit , dewan komisaris independen dan reputasi kap terhadap audit report lag. Prosiding Akuntansi.

Mufidah, N., \& Laily, N. (2019). Audit Tenure, Spesialisasi Industri Auditor, Dan Audit Report Lag pada Perusahaan Sektor Keuangan Di Bei Periode 2013-2017. Jurnal Reviu Akuntansi Dan Keuangan.

Oftika Sari, Einde Evana, N. D. K. (2019). Pengaruh Financial Distress, Opini Audit, dan Profitabilitas Terhadap Audit Report Lag. Jurnal Akuntansi Dan Keuangan.

Parahyta, C. H., \& Herawaty, V. (2020). Pengaruh Financial Distress, Profitabilitas, dan Audit Tenure terhadap Audit Report Lag dengan Ukuran Perusahaan Sebagai Variabel Moderasi. KOCENIN Serial Konferensi.

Putra Dewangga, R., \& Majidah. (2016). Analisis Determinasi Audit Report Lag. E-Proceeding of Management.

Putri, L. (2019). Pengaruh Opini Audit, Investment Opportunities Set, dan Auditor Spesialisasi Industri terhadap Audit Report Lag. E - Jurnal Universitas Pamulang.

Sawitri, N. M. D. C., \& Budiartha, I. K. (2018). Pengaruh Audit Tenure dan Financial Distress pada Audit Delay dengan Spesialisasi Auditor Sebagai Variabel Pemoderasi. E-Jurnal Akuntansi.

https://doi.org/10.24843/eja.2018.v22 .i03.p12

Sunaningsih, S. N., \& Rohman, A. (2013). Faktor-Faktor yang Berpengaruh terhadap Audit Delay (Studi Empiris pada Perusahaan Manufaktur yang Terdaftard di Bursa Efek Indonesia Tahun 2008). Diponegoro Journal of 
Accounting.

Van Caneghem, T. (2004). The impact of audit quality on earnings rounding-up behaviour: some UK evidence. European Accounting Review. https://doi.org/10.1080/09638180420 00216866

Wiratna, S. (2014). Metodologi penelitian lengkap, praktis dan mudah dipahami. Pt.Pustaka Baru.

Yudhi, Y. P., Ahmar, N., \& Syam, M. A. (2020). Determinan Audit Report Lag dan Peran Auditor Spesialisasi Industri Sebagai Pemoderasi Pada Perusahaan Badan Usaha Milik Negara. Jurnal Riset Akuntansi \& Perpajakan (JRAP). https://doi.org/10.35838/jrap.v7i01.14 96 